\title{
Insights into the Management of Overactive Bladder: What Difference Can Mirabegron Make?
}

\author{
Aşırı Aktif Mesane Tedavisinin Değişen Yüzü: Mirabegron'u Farklı Kılan Özellikler Ne \\ Olabilir?
}

\author{
(1) Ömer Acar1, (1) Mustafa Levent Erton², (1) Tufan Tarcan ${ }^{3}$ \\ ${ }^{1}$ Koç University Faculty of Medicine, Department of Urology, İstanbul, Turkiye \\ ${ }^{2}$ Astellas Pharma, İstanbul, Turkiye \\ 3 Marmara University Faculty of Medicine, Department of Urology, İstanbul, Turkiye
}

\begin{abstract}
Oral pharmacotherapy constitutes second-line treatment for overactive bladder (OAB) after lifestyle modifications, bladder retraining, and pelvic floor muscle exercises. Antimuscarinics have an established role in the treatment of OAB. However, antimuscarinics are known to have low persistence rates in clinical practice. Mirabegron is an oral $\beta 3$-adrenoreceptor agonist which has emerged as an alternative to antimuscarinics for managing OAB. Overall, mirabegron has similar clinical efficacy to antimuscarinics and is superior to placebo. Mirabegron has been generally well tolerated in both interventional and non-interventional studies. Persistence has been shown to be higher with mirabegron than with antimuscarinics in realworld studies. Increased blood pressure is associated with mirabegron and therefore its use is contraindicated in patients with severe uncontrolled hypertension. However, a low rate of treatment cessation due to cardiovascular issues has been noted in clinical trials. Mirabegron's utility in the elderly patient population has been well supported with promising efficacy and safety outcomes. New data from a prospective placebo-controlled randomized trial in older $\mathrm{OAB}$ patients is expected to be published soon. Mirabegron does not interfere with detrusor contractions during the emptying phase of the micturition cycle and hence lacks any significant effect on post-void residual volume. Mirabegron can be combined with antimuscarinics to synergize clinical effectiveness. Overall, mirabegron represents a well-tolerated and effective medical treatment option for OAB. Mirabegron could be used as an alternative to antimuscarinics, especially in patients who do not improve with antimuscarinics and/or experience bothersome side effects for whom anticholinergic load may be a relevant consideration.
\end{abstract}

Keywords: Overactive bladder, Pharmacotherapy, Antimuscarinic, Beta3 agonist, Side effects

Öz

Aşırı aktif mesane (AAM) sıklıkla karşılaşılan ve hayat kalitesini olumsuz yönde etkileyen bir sağlık sorunudur. AAM'nin tedavisinde ilk basamağı yaşam tarzı modifikasyonları, işeme alışkanlıklarının düzenlenmesi ve pelvik taban egzersizleri oluşturmaktadır. Antimuskariniklerin temelini temsil ettiği oral farmakoterapi, tedavide ikinci basamakta yer almaktadır. Ancak, antimuskariniklere bağlı yan etkiler ve tolerans sorunları, özellikle uzun vadede, tedaviye uyum oranını azaltmaktadır. Bir oral $\beta 3$-adrenerjik reseptör agonisti olan Mirabegron, AAM'nin medikal tedavisinde antimuskariniklere alternatif olarak geliştirilmiştir. Klinik etkinliğinin plasebo'dan daha üstün olduğu kanıtlanmıştır. Genel olarak, antimuskarinikler ile benzer klinik etkinliğe sahiptir. Klinik çalışmalarda genellikle iyi tolere edildiği tespit edilmiştir. Mirabegron kan basıncını yükseltebilir ve dolayısıyla ağır, kontrolsüz hipertansiyon varlığında kullanımı kontrendikedir. Kardiyovasküler yan etkilere bağlı olarak tedaviyi sonlandırma oranı oldukça düşüktür. Geriyatrik hasta grubunda da etkin ve güvenilir bir şekilde kullanılabileceğini destekleyen çalışmalar yayınlanmıştır. Henüz devam etmekte olan prospektif plasebo-kontrollü randomize çalışmasının sonuçları, Mirabegron'un AAM tedavisindeki yerini daha da aydınlatacaktır. Mirabegron'un boşaltım fazındaki detrusor kontraksiyonlarını engellemediği hayvan çalışmalarında gösterilmiştir. Dolayısıyla, post-miksiyonel rezidüel idrar miktarını anlamlı düzeyde yükseltmemektedir. Klinik etkinliği sinerjistik olarak arttırmak adına mirabegron ve antimuskarinikler kombine olarak kullanılabilir. Sonuç olarak mirabegron, AAM'nin medikal tedavisinde tercih edilebilecek, etkin, güvenilir ve iyi tolere edilen bir oral farmakoterapi seçeneğidir. Özellikle antimuskarinik tedaviye rağmen yakınmaları devam eden, antikolinerjik yan etkilerden muzdarip ve/veya total antikolinerjik ilaç yükünün fazla olduğu hastalarda antimuskarinik ilaçların yerine tercih edilebilir.

Anahtar Kelimeler: Aşırı aktif mesane, Farmakoterapi, Antimuskarinik, Beta3 agonist, Yan etki

Correspondence: Tufan Tarcan MD, Marmara University Faculty of Medicine, Department of Urology, ístanbul, Turkiye

Phone: +90 5434948365 E-mail: bilgi@tufantarcan.com ORCID-ID: orcid.org/0000-0002-3387-3524

Received: 12.01.2019 Accepted: 18.03.2019

Cite this article as: Acar Ö, Erton ML, Tarcan T. Insights into the Management of Overactive Bladder: What Difference Can Mirabegron Make? J Urol Surg 2019;6(2):85-92.

๑Copyright 2019 by the Association of Urological Surgery / Journal of Urological Surgery published by Galenos Publishing House. 


\section{Introduction}

Overactive Bladder (OAB) syndrome comprises a constellation of symptoms, defined by urinary urgency, with or without urgency urinary incontinence (UUI), usually accompanied by frequency and nocturia, in the absence of urinary tract infection (UTI) or any other obvious pathology (1). OAB affects up to $17 \%$ of the adults in Europe and the USA (2). Lifestyle changes, bladder retraining, and pelvic floor muscle exercises constitute the firstline treatment options for $\mathrm{OAB}$. Second-line treatment consists of oral pharmacotherapy and antimuscarinics represent the mainstay therapies in this setting (3). However, antimuscarinics are associated with a high incidence of bothersome anticholinergic side effects, such as dry mouth and constipation. In addition to a lack of efficacy, these tolerability issues are one of the most important factors underlying the low persistence rates associated with antimuscarinic therapy (4).

Mirabegron is an oral $\beta 3$-adrenoreceptor agonist which has emerged as an alternative to antimuscarinics for the medical treatment of OAB. Superior results in key efficacy parameters (micturition frequency and incontinence episodes) as well as quality of life ( $\mathrm{OoL}$ ) measures have been noted with mirabegron compared with placebo in phase III trials. Moreover, the sideeffect profile for mirabegron seems favorable with the rates of adverse events being similar to that for placebo and the incidence of dry mouth being lower than that for antimuscarinics $(5,6,7)$. Furthermore, mirabegron was shown to be as efficacious as antimuscarinics (except for solifenacin $10 \mathrm{mg}$ ) in a recent systematic literature review (8). The 12-month persistence rate for mirabegron was also found to be significantly higher than that recorded for antimuscarinics (9).

Herein, we will provide a non-systematic review of the contemporary literature about the safety and efficacy of mirabegron for the treatment of $O A B$, with particular emphasis on the potential clinical benefits mirabegron might offer based on its pharmacological properties.

\section{Basic Pathophysiology of Overactive Bladder}

Partially overlapping theories exist regarding the pathophysiology of OAB. The urothelium-based hypothesis suggests that functional changes involving the urothelial receptors and the sensitivity and coupling of the suburothelial myofibroblasts will ultimately lead to increasing activity of afferent signals and urgency (10). The myogenic hypothesis relies on the assumption that unstable detrusor contractions may be triggered by changes in their excitability as well as coupling with other myocytes or myofibroblasts. Unstable detrusor contractions generate increased afferent activity, which eventually causes OAB symptoms (11). The hallmark of the neurogenic hypothesis is abnormal processing of afferent signals, possibly the result of altered central inhibitory pathways, which cause sensitization of afferent nerves, activation of the micturition reflex, and induction of unstable detrusor contractions (12). Hormonal and psychological influences, which are beyond the scope of this article, may also have a role in the pathophysiology of $O A B(13)$.

\section{Epidemiology of Overactive Bladder}

$O A B$ is a common disorder with a negative influence on QoL. The estimated prevalence is approximately $10 \%$, which means the $O A B$ syndrome affects more than 500 million individuals globally (14). The prevalence of $O A B$ increases with age with up to $41 \%$ of men and $31 \%$ of women aged $>75$ years having symptoms consistent with $O A B$ (15). It should be noted that many symptomatic patients do not seek medical advice due to several barriers, including embarrassment and poor communication. Benner et al. (16) have estimated that less than half of the patients with bothersome $O A B$ symptoms consult a physician and receive some form of treatment for $O A B$. Furthermore, patients with $O A B$ often wait for a prolonged period before seeking healthcare provision (17). Therefore, the actual prevalence of $O A B$ could be significantly higher than that reported in the literature.

\section{Current Challenges in the Management of Overactive Bladder}

Antimuscarinics, which exert their clinical effect via antagonizing the acetylcholine involved in the activation of muscarinic receptors in the bladder, have comprised the mainstay of $O A B$ treatment. There are five different muscarinic receptor subtypes (M1 to M5) with M3 being the most important one for mediating detrusor contractions (18). However, muscarinic receptors do not exist only in the bladder. They are widely distributed throughout the body; with the brain, heart, eyes, salivary glands, and gastrointestinal tract relying on muscarinic receptor subtypes for optimal functioning (18). This distribution pattern, together with the relative binding affinity of antimuscarinics to each muscarinic receptor subtype and the ability of antimuscarinics to cross the blood-brain barrier (BBB) (Table 1), accounts for the commonly encountered side effects of antimuscarinic agents, such as constipation, dry mouth, blurred vision, increased heart rate, and dizziness (19).

Age-related changes in the body, such as the BBB becoming more permeable, muscarinic receptor density in the brain being lower, and overall drug metabolism being less efficient, increase the risk of central nervous system (CNS) related drug adverse events in the elderly patient population $(20,21)$. Polypharmacy and the possibility of drug interactions leading to clinical inefficacy and/or unwanted adverse reactions should also be considered while prescribing medications to the elderly.

All five muscarinic receptor subtypes are expressed in the brain with the antagonism of M1 having the greatest impact 
on cognitive function, although M2 and M4 receptors may also have a role on central regulation (22). CNS side effects, such as somnolence, fatigue, confusion, delirium, impaired attention, delayed memory, visual disturbances, dizziness, and cognitive impairment, can occur when antimuscarinics cross the BBB (23). Furthermore, some investigations have indicated that the cumulative use of drugs with anticholinergic effects (known as anticholinergic burden) could be associated with negative outcomes such as cognitive impairment $(24,25)$. In 2015, American Geriatric Society updated the Beers Criteria for potentially inappropriate medication use in older adults and indicated antimuscarinics as potentially inappropriate medications that should be avoided in elderly patients (26).

New generation antimuscarinics exhibit stronger selectivity and affinity for $\mathrm{M} 2$ and $\mathrm{M} 3$ receptors, which may improve tolerability by means of minimizing extra-urinary side effects. However, a recent literature review demonstrated that $43-83 \%$ of women still withdraw their antimuscarinic treatment by 1 month, and that less than $35 \%$ of women continue their medication after the first year, primarily because of intolerable adverse effects (27).

Treatment compliance is of utmost importance for a successful outcome in the management of chronic conditions such as $O A B$. Despite their established clinical efficacy in the medical treatment of $O A B$, the side effects, tolerability issues, and low persistence rates associated with antimuscarinic drugs have contributed to the development of alternative, non-muscarinic targets for $O A B$ pharmacotherapy. Drugs with potentially less bothersome anticholinergic side effects may have a positive influence on improved medication adherence and, ultimately, treatment outcome. This rationale led to the development of mirabegron, which was introduced throughout Europe in 2012 as an alternative drug for the treatment of OAB.

\section{Pharmacological Properties of Mirabegron}

Mirabegron is an oral, selective $\beta 3$-adrenoreceptor agonist which improves $O A B$ symptoms. In the human bladder, three $\beta$ adrenoreceptor subtypes $(\beta 1, \beta 2$, and $\beta 3)$ have been identified in the detrusor muscle and urothelium. The $\beta 3$ adrenoreceptor accounts for $97 \%$ of total $\beta$-adrenoreceptor messenger ribonucleic acid transcripts in the bladder and is the main adrenergic receptor subtype that mediates the relaxation of the detrusor smooth muscle during the storage phase of the micturition cycle $(28,29)$. The $\beta 3$-adrenoceptor is a transmembrane $\mathrm{G}$ protein-coupled receptor, with extracellular $\mathrm{N}$-terminal and intracellular C-terminal tails, made up of 408 amino acids. When activated by the ligand (epinephrine, norepinephrine), the receptor couples to a specific $G$ protein $\left(G_{s}\right)$ which in turn stimulates adenylate cyclase, resulting in increased intracellular levels of cyclic adenosine monophosphate (cAMP) (30). Elevated cAMP levels lead to detrusor smooth muscle relaxation and improved storage capacity without significant changes in bladder contraction during voiding or post-void residual (PVR) volume $(31,32,33,34,35)$. There is additional evidence showing that acetylcholine-containing nerve fibers of the human bladder express immunoreactivity for the $\beta 3$ adrenoreceptor (36).

$\beta$-adrenergic agonists, including the $\beta 3$ subtype, are important regulators of human cardiac function (37). As a result, cardiovascular (CV) side-effects (OT prolongation, hypertension, atrial fibrillation, and tachycardia) are relevant considerations in the clinical development and use of such therapeutics (38). Clinically relevant OT prolongation has not, however, been observed with mirabegron in clinical studies (39). As patients

Table 2. Basic pharmacological properties of mirabegron

\begin{tabular}{ll}
\hline Trade names & Myrbetriq, betamis, betmiga \\
\hline Formula & $\mathrm{C}_{21} \mathrm{H}_{24} \mathrm{~N}_{4} \mathrm{O}_{2} \mathrm{~S}$ \\
\hline Molecular weight & $396.5 \mathrm{~g} / \mathrm{mol}$ \\
\hline Dose & $25 \mathrm{or} 50 \mathrm{mg}$ per day \\
\hline Route of administration & Oral \\
\hline Bioavailability & $29 \%$ (25 mg dose), 35\% (50 mg dose) \\
\hline Half-life & 50 hours \\
\hline Metabolism & Mainly by CYP3A4 \\
\hline Elimination & Urine (55\%), feces (34\%) \\
\hline CYP: Cytochrome P450 &
\end{tabular}

Table 1. Basic characteristics of the antimuscarinic drugs

\begin{tabular}{llll}
\hline & Molecular weight (kDa) & Ability to cross BBB & Selectivity \\
\hline Darifenacin & 507.5 & Low & M3 \\
\hline Fesoterodine & 527.6 & Low & Non-selective \\
\hline Oxybutynin & 393.9 & High & Non-selective \\
\hline Propiverine & $403.9^{*}$ & Limited data & Non-selective \\
\hline Solifenacin & 480.5 & Moderate & Predominantly M3 \\
\hline Tolterodine & 475.6 & Moderate & Non-selective \\
\hline Trospium & 427.9 & Low & Non-selective \\
\hline
\end{tabular}

BBB: Blood-brain barrier, *Value expressed in $\mathrm{g} / \mathrm{mol}$ 
with a known history of QT prolongation, or patients who are taking medicinal products known to prolong the OT interval, were not included in these studies, the effects of mirabegron in these patients is currently unknown. Physicians should therefore exercise caution when administering mirabegron to these patients.

In terms of the functioning of the $\beta$ adrenoreceptor subtypes, studies have shown that $\beta 1$-mediated effects increase heart rate and the force of cardiac contraction, while $\beta 3$-adrenoceptors trigger positive inotropic effects in human atrial tissue and negative inotropic effects in ventricular tissue (40). $\beta 2$ adrenoceptors are mainly located in vascular smooth muscles and they mediate vasodilation, especially in arteriolar beds located in the extremities (41). Mirabegron has a higher in vitro affinity for the $\beta 3$ adrenergic receptor compared with the $\beta 1$ (150-fold) and $\beta 2$ (33-fold) subtypes (42).

According to the Food and Drug Administration label, the initial standard dosing for mirabegron is $25 \mathrm{mg}$ orally once a day, but this can be increased to $50 \mathrm{mg}$ based on clinical efficacy and tolerability (43). In the countries which are located in the territory of the European Medicines Agency (such as Turkiye), $50 \mathrm{mg}$ once daily is the recommended dose (39). Therefore, if mirabegron treatment is initiated at $50 \mathrm{mg}$ orally once a day, particular attention needs to be given to monitoring possible side effects, as well as clinical efficacy, during the first weeks of treatment. Mirabegron is rapidly absorbed following oral administration, with a time to maximal plasma concentration (tmax) of 3-4 $\mathrm{h}$ and a terminal plasma half-life of $\sim 50 \mathrm{~h}$, and $\sim 71 \%$ is bound to plasma proteins $(42,44)$. The basic pharmacological properties of mirabegron are summarized in Table 2.

\section{Clinical Studies and Guideline Recommendations Concerning Mirabegron}

The findings from three pivotal, large-scale, 12-week, multicenter, randomized, controlled phase III trials have been used to demonstrate the safety and efficacy of mirabegron for the treatment of $O A B(5,6,7)$. Significant improvements in the primary end points (mean number of incontinence episodes per $24 \mathrm{~h}$ and mean number of micturitions per $24 \mathrm{~h}$ ) have been observed with mirabegron in comparison with placebo. Secondary efficacy measures, such as mean volume voided per micturition, mean number of urgency episodes per $24 \mathrm{~h}$, and QoL assessments, also improved significantly following mirabegron treatment. Overall, the safety profile was favorable in these studies with the incidence of adverse events being similar for mirabegron and for placebo. Furthermore, the incidences of hypertension and the effects on vital signs were similar with mirabegron, tolterodine, and placebo $(5,6,7,45)$.

In an observational population-based study, Chapple et al. (9) compared the persistence with and adherence to mirabegron and antimuscarinics. Median time to discontinuation and the 12-month persistence rates were significantly higher with mirabegron. Wagg et al. (46) have reported significantly improved 6-month adherence rates with mirabegron compared with antimuscarinics, with median medication possession ratios (i.e., the proportion of days the patient received the prescribed medication compared to their overall time on therapy) of $65 \%$ vs $19 \%-49 \%$, respectively.

In the BEYOND study, in which mirabegron $50 \mathrm{mg}$ was compared with solifenacin $5 \mathrm{mg}$, the degree of improvement in key $O A B$ symptoms were similar between the two groups and both classes of drug were well tolerated (47). In terms of the primary end point of mean number of micturitions / $24 h$, the results of the BEYOND study were inconclusive, with the non-inferiority of mirabegron and the superiority of solifenacin not being demonstrated due to the wide confidence interval obtained. Likewise, Maman et al. (8) did not find significant differences between the efficacy and overall safety of mirabegron and antimuscarinics in their recent systematic review which covered relevant $O A B$ management articles published between 2000 and 2013. The authors highlighted the fact that mirabegron treatment was associated with a lower incidence of dry mouth which may serve as an aid to improve adherence.

Kelleher et al. (48) conducted a comprehensive, systematic literature review and network meta-analysis which included the randomized controlled trials conducted between 2000 and 2017 that assessed treatment outcomes for OAB. This analysis included 64 studies and over 46.000 patients. In this study, mirabegron $50 \mathrm{mg}$ was found to be significantly more efficacious than placebo for all efficacy measures, including micturition frequency, UUI, dry rate, and 50\% reduction in incontinence. Mirabegron $50 \mathrm{mg}$ was also found to be as efficacious as most of the other active treatments, except for solifenacin $10 \mathrm{mg}$ monotherapy and solifenacin $5 \mathrm{mg}$ plus mirabegron 25 or 50 $\mathrm{mg}$ in combination, which yielded superior outcomes for some/ all end points. Regarding safety, the likelihood of dry mouth, constipation, and urinary retention were significantly lower for mirabegron $50 \mathrm{mg}$ compared with the other active treatments in the majority of the included studies (48).

The American Urological Association (AUA) and the Society of Urodynamics, Female Pelvic Medicine and Urogenital Reconstruction (SUFU) recommended that antimuscarinics or mirabegron should be offered as second-line therapies after failed or inadequately effective behavioral treatments (49). According to these guidelines, oral pharmacotherapy (either with antimuscarinics or mirabegron) can also be combined with behavioral modifications in the first-line treatment setting. Conversely, the European Association of Urology (EAU) recommended antimuscarinic drugs or mirabegron for adults with UUI who have failed conservative treatment (3). 


\section{Combination Therapy with Antimuscarinics and Mirabegron}

The double-blind, multicenter BESIDE trial evaluated the safety and efficacy of solifenacin $5 \mathrm{mg}+$ mirabegron $50 \mathrm{mg}$ versus solifenacin $5 \mathrm{mg}$ and $10 \mathrm{mg}$ (50). The trial showed that the combination group had superior results compared with the solifenacin $5 \mathrm{mg}$ group in terms of daily micturition and incontinence episodes. With regards to daily micturition frequency, the difference between the combination group and the solifenacin $10 \mathrm{mg}$ group was significantly different in favor of the combination arm. In addition, the combination was non-inferior to solifenacin $10 \mathrm{mg}$ with respect to the number of incontinence episodes reported at the end of treatment using a 3-day diary period. The SYMPHONY trial was designed to assess the safety and efficacy of combination treatment with mirabegron and solifenacin in patients with $O A B$ and included various dose-ranging combinations and a total of 12 groups (51). The solifenacin 5/10 mg + mirabegron 25/50 mg combinations provided significantly better results in terms of primary outcome measures compared with solifenacin 5 $\mathrm{mg}$ and placebo. Another large-scale trial (SYNERGY), which randomized over 3.500 patients into monotherapy (with either solifenacin or mirabegron) or combination treatment groups, demonstrated numerically better outcomes for the combination arms with regards to most of the efficacy measures. Despite the greater clinical improvement, the incidences of adverse events (dry mouth and constipation) were higher in the combination therapy groups compared with the respective monotherapy and placebo groups (52).

The EAU guidelines recommended that the addition of mirabegron, rather than dose escalation, would be beneficial for patients who were inadequately treated with solifenacin $5 \mathrm{mg}$ alone (3). On the contrary, the AUA/SUFU guidelines state that in cases of inadequate symptom relief and/or intolerable side effects with one antimuscarinic medication, dose modification or switching to a different antimuscarinic medication or mirabegron can be attempted (49).

\section{Mirabegron in the Elderly Patient Population}

Wagg et al. (53) investigated the safety and efficacy of mirabegron following administration to elderly patients in a prospective subanalysis of individual and pooled data from three 12-week, randomized, phase III trials, and a 1-year safety trial. This study showed that 12 weeks of once daily treatment with mirabegron $25 \mathrm{mg}$ or $50 \mathrm{mg}$ reduced the mean numbers of incontinence episodes per $24 \mathrm{~h}$ and micturitions per $24 \mathrm{~h}$ in the subgroups of patients aged $\beta 65$ years and $\beta 75$ years. Mirabegron was well tolerated in both age groups, with hypertension and UTI being the most common treatment-emergent adverse events and dry mouth being seldom reported. The incidence of side effects that led to discontinuation of mirabegron was low and comparable across the mirabegron $25 \mathrm{mg}$, mirabegron 50 $\mathrm{mg}$, and placebo groups in patients aged $\beta 65$ years (53).

Despite concerns about possible CV adverse effects, mirabegron appears to have an acceptable CV safety profile at therapeutic doses. Analysis of the pooled data from three phase III 12-week trials showed that the use of mirabegron $50 \mathrm{mg}$ led to clinically insignificant and reversible rises in systolic and diastolic blood pressure and pulse rate compared with placebo (54). In a longer (1 year) phase III study which included an active control group, the frequency of tachycardia was lower with mirabegron $50 \mathrm{mg}$ compared with tolterodine (55). Additionally, the incidence of hypertension in the oldest patient group ( $\beta 75$ years) was higher with tolterodine (14.5\%) than with mirabegron $50 \mathrm{mg}(9.3 \%)$ (53).

Although there is evidence demonstrating the acceptable CV safety profile of mirabegron in elderly patients, it is important to note that the therapeutic is contraindicated for use in patients with severe uncontrolled hypertension (systolic blood pressure $\beta 180 \mathrm{mmHg}$ and/or diastolic blood pressure $\beta 110$ $\mathrm{mmHg}$ ) (43). Nevertheless, in older patients, when switching between antimuscarinic drugs fails to improve efficacy and/or tolerability issues occur, or where there is already an existing anticholinergic burden, the use of mirabegron may be preferred (38).

\section{Concomitant Use of Mirabegron and $\beta$-blockers}

The potential interaction between $\beta$-blockers and mirabegron has been investigated in a pooled analysis of large-scale clinical trials (56). This analysis showed that the clinical efficacy of mirabegron (in terms of the reduction in mean number of incontinence episodes and micturitions per $24 \mathrm{~h}$ ) did not change significantly following concomitant $\beta$-blocker treatment. Additionally, the tolerability profile of mirabegron was similar between patients who were using $\beta$-blockers and those who were $\beta$-blocker naive. Lastly, mirabegron did not attenuate the $\mathrm{CV}$ responses associated with the administration of metoprolol, which is a selective $\beta 1$ antagonist. A further study in healthy volunteers showed that the inhibitory potency of mirabegron towards cytochrome P450 2D6 (CYP2D6) is moderate and the CYP2D6 activity recovers within 15 days after discontinuation of mirabegron (39). Multiple once daily dosing of immediaterelease mirabegron increases the maximal plasma concentration (Cmax) and area under the curve of a single dose of metoprolol by $90 \%$ and $229 \%$, respectively.

\section{Utility of Mirabegron Together with Digoxin or Warfarin}

Digoxin and warfarin are involved in many drug interactions due to their narrow therapeutic index. Small pharmacokinetic alterations following concomitant use of these drugs can lead to diminished therapeutic effects or toxic adverse reactions. 
Digoxin is widely used as a medication to enhance cardiac contractility and it is metabolized via the P-glycoprotein ( $\mathrm{P}$ gp) efflux transporter. Groen-Wijnberg et al. (57) have found that mirabegron increased digoxin exposure by almost $30 \%$, indicating that mirabegron is an inhibitor of $\mathrm{P}-\mathrm{gp}$ in vivo. Therefore, patients receiving mirabegron with digoxin may require more intense monitoring of digoxin concentrations and dosage readjustments may be frequently required. For example, patients, who are commencing treatment with a combination of mirabegron and digoxin, should be initially prescribed the lowest dose of digoxin (39). Serum digoxin concentrations should then be monitored and utilized for titration of the digoxin dose in order to obtain the desired clinical effect. Furthermore, the potential for inhibition of P-gp by mirabegron should be considered when the therapeutic is combined with sensitive P-gp substrates, for example dabigatran. The pharmacokinetic interactions between mirabegron and warfarin have also been assessed (57). This study found that the co-administration of mirabegron and warfarin had no significant effect on the pharmacokinetic profile and international normalized ratio of warfarin. Hence, no dosage adjustment of warfarin is necessary when it is used concomitantly with mirabegron.

Physicians are advised to be cautious if they co-administer mirabegron with medicinal products that have a narrow therapeutic index and are significantly metabolized by CYP2D6, such as thioridazine, Type 1C antiarrhythmics (e.g., flecainide, propafenone) and tricyclic antidepressants (e.g., imipramine, desipramine) (39). Caution is also advised if mirabegron is coadministered with CYP2D6 substrates that are individually dose titrated.

\section{Other Potential Clinical Utilities of Mirabegron}

Bladder contractility decreases with aging, which means that older patients with $O A B$ have an increased risk of experiencing urinary retention. Currently, it is typically recommended to avoid antimuscarinics in men with PVR volumes that exceed $150 \mathrm{~mL}$ (58). However, the risk of acute urinary retention in male patients who received treatment with antimuscarinics due to lower urinary tract symptoms (LUTS) has been reported to be less than 3\% (59).

Animal studies suggest that the myorelaxant action of mirabegron occurs during the storage phase. Hence, mirabegron does not significantly influence micturition pressure, PVR volume, or detrusor contraction during voiding $(33,34,35)$. In a 12-week phase II study, which included male patients with LUTS and bladder outlet obstruction, mirabegron did not adversely affect maximum urinary flow rate and detrusor pressure at maximum urinary flow compared with placebo (60). Considering these facts, the use of mirabegron instead of antimuscarinics may be preferred in elderly male patients with $\mathrm{OAB}$ and emptying phase symptoms, significant PVR, or a history of urinary retention.
The incidence of glaucoma increases with age and antimuscarinics are contraindicated for patients with narrow-angle glaucoma (61). In a randomized, placebo-controlled study involving adult patients with normal intraocular pressure, mirabegron did not cause elevations in intraocular pressure and the incidence of ocular adverse events was similarly low in mirabegron and placebo groups (62).

\section{Conclusions}

$O A B$ is a prevalent disorder which can have a significant impact on QoL. Behavioral therapy and/or oral pharmacotherapy constitute the recommended initial treatment options. Antimuscarinics represent the mainstay of medical treatment for OAB. Despite being efficacious therapeutics, bothersome anticholinergic adverse effects limit the clinical utility of antimuscarinics and hamper long-term persistence rates. Mirabegron has been introduced as an alternative to antimuscarinics for the treatment of $\mathrm{OAB}$. By stimulating $\beta 3$-adrenoceptors, mirabegron causes bladder relaxation during the storage phase of the micturition cycle. Furthermore, mirabegron has no significant effect on bladder contractility and PVR volume. In terms of clinical efficacy, mirabegron has been shown to be significantly more effective than placebo with regards to improving $O A B$ symptoms. Despite the rarity of head-to-head comparisons, a systematic review showed that mirabegron had similar efficacy to most antimuscarinics (except solifenacin $10 \mathrm{mg}$ ) in terms of the improvement recorded in key efficacy measures. Mirabegron has a favorable overall tolerability profile with a similar incidence of adverse events to placebo. Anticholinergic side effects (such as dry mouth, constipation, and blurred vision), which represent the main reason for antimuscarinic nonadherence, are less frequent with mirabegron. CNS-related side effects have been seldom reported and the CV safety profile is acceptable with no clinically significant alterations in blood pressure and heart rate being recorded in clinical studies. Given its efficacy and favorable adverse effect profile, mirabegron has a definite role in the medical management of $O A B$, including for those patients who were inadequately treated with antimuscarinics or were bothered by antimuscarinic side effects. Mirabegron could also be used in patients for whom anticholinergic burden preclude antimuscarinic usage (especially the elderly patient population) or patients with emptying phase symptoms and elevated PVR volume that is associated with the clinical picture. It appears that mirabegron is a useful addition to the variety of treatment options available for $O A B$ and the findings from ongoing clinical trials with mirabegron (e.g., the prospective, placebo-controlled, randomized PILLAR trial) are awaited with particular interest.

\section{Ethics}

Peer-review: Externally peer-reviewed. 


\section{Authors Contrubius}

Concept: T.T., M.L.E., Design: T.T., M.L.E., Ö.A., Literature search: Ö.A., M.L.E., Data Analysis or Interpretation: Ö.A., T.T., M.L.E., Drafting the Manuscript: Ö.A., T.T., Revision of the manuscript: Ö.A., T.T.

Conflict of Interest: No conflict of interest was declared by the authors.

Financial Disclosure: Dr. Ömer Acar, advisor for Astellas. Dr. Mustafa Levent Erton, Medical Manager at Astellas. Dr. Tufan Tarcan, acted as adviser or speaker or received travel grants from Astellas, Recordati, Pierre Fabre, Pfizer, Abdi İbrahim, and Santa Farma. The development of this publication was funded by Astellas. Editorial assistance was provided by Michael Parsons, PhD, CMPP of Envision Scientific Solutions and funded by Astellas Pharma Global Development.

\section{References}

1. Abrams $P$, Cardozo L, Fall M, Griffiths D, Rosier P, Ulmsten U, Van Kerrebroeck $\mathrm{P}$, Victor A, Wein A. The standardisation of terminology in lower urinary tract function: report from the standardisation sub-committee of the International Continence Society. Urology 2003;61:37-49.

2. Stewart WF, Van Rooyen JB, Cundiff GW, Abrams P, Herzog AR, Corey R, Hunt $\mathrm{TL}$, Wein AJ. Prevalence and burden of overactive bladder in the United States. World J Urol 2003;20:327-336.

3. Burkhard FC, Bosch JLHR, Cruz F, Lemack GE, Nambiar AK, Thiruchelvam N, Tubaro A. EAU urinary incontinence guidelines 2018. Available at https:// uroweb.org/guideline/urinary-incontinence/ (last accessed 21 November 2018).

4. Benner JS, Nichol MB, Rovner ES, Jumadilova Z, Alvir J, Hussein M, Fanning K, Trocio JN, Brubaker L. Patient-reported reasons for discontinuing overactive bladder medication. BJU Int 2010;105:1276-1282.

5. Nitti VW, Auerbach S, Martin N, Calhoun A, Lee M, Herschorn S. Results of a randomized phase III trial of mirabegron in patients with overactive bladder. J Urol 2013;189:1388-1395.

6. Khullar V, Amarenco G, Angulo JC, Cambronero J, Høye K, Milsom I, Radziszewski $P$, Rechberger $T$, Boerrigter $P$, Drogendijk $T$, Wooning $M$, Chapple C. Efficacy and tolerability of mirabegron, a $\beta 3$-adrenoceptor agonist, in patients with overactive bladder: results from a randomised European-Australian phase 3 trial. Eur Urol 2013;63:283-295.

7. Herschorn $S$, Barkin J, Castro-Diaz D, Frankel JM, Espuna-Pons M, Gousse AE, Stölzel M, Martin N, Gunther A, Van Kerrebroeck P. A phase III, randomized, double-blind, parallel-group, placebo-controlled, multicentre study to assess the efficacy and safety of the $\beta 3$ adrenoceptor agonist, mirabegron, in patients with symptoms of overactive bladder. Urology 2013;82:313-320.

8. Maman K, Aballea S, Nazir J, Desroziers K, Neine M-E, Siddiqui E, Odeyemi I, Hakimi Z. Comparative efficacy and safety of medical treatments for the management of overactive bladder: a systematic literature review and mixed treatment comparison. Eur Urol 2014;65:755-765.

9. Chapple CR, Nazir J, Hakimi Z, Bowditch S, Fatoye F, Guelfucci F, Khemiri $A$, Siddiqui $E$, Wagg A. Persistence and adherence with mirabegron versus antimuscarinic agents in patients with overactive bladder: a retrospective observational study in UK clinical practice. Eur Urol 2017;72:389-399.

10. Steers WD. Pathophysiology of overactive bladder and urge urinary incontinence. Rev Urol 2002;4 (Suppl 4):S7-S18.

11. Brading AF. A myogenic basis for the overactive bladder. Urology 1997;50:5767.
12. Miller J, Hoffman E. The causes and consequences of overactive bladder. J Womens Health (Larchmt) 2006;15:251-260.

13. Banakhar MA, Al-Shaiji TF, Hassouna MM. Pathophysiology of overactive bladder. Int Urogynecol J 2012;23:975-982.

14. Irwin DE, Kopp ZS, Agatep B, Milsom I, Abrams P. Worldwide prevalence estimates of lower urinary tract symptoms, overactive bladder, urinary incontinence and bladder outlet obstruction. BJU Int 2011;108:1132-1138.

15. Milsom I, Stewart $W_{1}$ Thüroff J. The prevalence of overactive bladder. Am J Manag Care 2000;6:565-573.

16. Benner JS, Becker R, Fanning K, Jumadilova Z, Bavendam T, Brubaker L; OAB Medication Use Study Steering Committee. Bother related to bladder control and health care seeking behavior in adults in the United States. J Urol 2009;181:2591-2598.

17. Filipetto $F A$, Fulda $K G$, Holthusen $A E$, McKeithen $T M$, McFadden P. The patient perspective on overactive bladder: a mixed-methods needs assessment. BMC Fam Pract 2014;15:96.

18. Yamanishi T, Chapple CR, Chess-Williams R. Which muscarinic receptor is important in the bladder? World J Urol 2001;19:299-306.

19. Çetinel B, Onal B. Rationale for the use of anticholinergic agents in overactive bladder with regard to central nervous system and cardiovascular system side effects. Korean J Urol 2013;54:806-815.

20. Kleine TO, Hackler R, Zöfel P. Age-related alterations of the blood-brainbarrier (bbb) permeability to protein molecules of different size. Z Gerontol 1993;26:256-259.

21. Blennow K, Fredman P, Wallin A, Gottfries C-G, Karlsson I, Långstrom G, Skoog I, Svennerholm L, Wikkelsö C. Protein analysis in cerebrospinal fluid. II. Reference values derived from healthy individuals 18-88 years of age. Eur Neurol 1993;33:129-133.

22. Anagnostaras SG, Murphy GG, Hamilton SE, Mitchell SL, Rahnama NP, Nathanson NM, Silva AJ. Selective cognitive dysfunction in acetylcholine M1 muscarinic receptor mutant mice. Nat Neurosci 2003;6:51-58.

23. Abrams P, Andersson K-E, Buccafusco JJ, Chapple C, de Groat WC, Fryer AD, Kay G, Laties A, Nathanson NM, Pasricha PJ, Wein AJ. Muscarinic receptors: their distribution and function in body systems, and the implications for treating overactive bladder. Br J Pharmacol 2006;148:565-578.

24. Gray SL, Anderson ML, Dublin S, Hanlon JT, Hubbard R, Walker R, Yu O, Crane PK, Larson EB. Cumulative use of strong anticholinergics and incident dementia: a prospective cohort study. JAMA Intern Med 2015;175:401-407.

25. Gray $\mathrm{SL}$, Anderson $\mathrm{ML}$, Hanlon JT, Dublin $\mathrm{S}$, Walker RL, Hubbard RA, Yu 0 , Montine TJ, Crane PK, Sonnen JA, Keene CD, Larson EB. Exposure to strong anticholinergic medications and dementia-related neuropathology in a community-based autopsy cohort. J Alzheimers Dis 2018;65:607-616.

26. By the American Geriatrics Society 2015 Beers Criteria Update Expert Panel. American Geriatrics Society 2015 updated Beers Criteria for potentially inappropriate medication use in older adults. J Am Geriatr Soc 2015;63:22272246.

27. Sexton CC, Notte SM, Maroulis C, Dmochowski RR, Cardozo L, Subramanian D, Coyne KS. Persistence and adherence in the treatment of overactive bladder syndrome with anticholinergic therapy: a systematic review of the literature. Int J Clin Pract 2011;65:567-585.

28. Nomiya $\mathrm{M}$, Yamaguchi 0 . A quantitative analysis of mRNA expression of $\beta 1$ and $\beta$-adrenoceptor subtypes and their functional roles in human normal and obstructed bladders. J Urol 2003;170:649-653.

29. Yamaguchi 0, Chapple CR. $\beta 3$-adrenoceptors in urinary bladder. Neurourol Urodyn 2007;26:752-756.

30. Dehvari $N$, da Silva Junior ED, Bengtsson T, Hutchinson DS. Mirabegron: potential off target effects and uses beyond the bladder. Br J Pharmacol 2018;175:40724082. 
31. Igawa Y, Yamazaki Y, Takeda H, Hayakawa K, Akahane M, Ajisawa Y, Yoneyama T, Nishizawa O, Andersson K-E. Functional and molecular biological evidence for a possible $\beta 3$-adrenoceptor in the human detrusor muscle. Br J Pharmacol 1999;126:819-825.

32. Takeda M, Obara K, Mizusawa T, Tomita Y, Arai K, Tsutsui T, Hatano A, Takahashi $\mathrm{K}$, Nomura $\mathrm{S}$. Evidence for $\beta 3$-adrenoceptor subtypes in relaxation of the human urinary bladder detrusor: analysis by molecular biological and pharmacological methods. J Pharmacol Exp Ther 1999;288:1367-1373.

33. Andersson K-E. Prospective pharmacologic therapies for the overactive bladder. Ther Adv Urol 2009;1:71-83.

34. Leon LA, Hoffman BE, Gardner SD, Laping NJ, Evans C, Lashinger ESR, Su X. Effects of the $\beta 3$-adrenergic receptor agonist disodium 5-[(2R)-2-[[(2R)2-(3-chlorophenyl)-2-hydroxyethyl]amino]propyl]-1,3-benzodioxole-2,2dicarboxylate (CL-316243) on bladder micturition reflex in spontaneously hypertensive rats. J Pharmacol Exp Ther 2008;326:178-185.

35. Tyagi $P_{1}$ Tyagi V. Mirabegron, a $\beta 3$-adrenoceptor agonist for the potential treatment of urinary frequency, urinary incontinence or urgency associated with overactive bladder. IDrugs 2010;13:713-722.

36. Coelho A, Antunes-Lopes T, Gillespie J, Cruz F. Beta-3 adrenergic receptor is expressed in acetylcholine-containing nerve fibers of the human urinary bladder: An immunohistochemical study. Neurourol Urodyn 2017;36:1972-1980.

37. Cannavo A, Koch WJ. Targeting $\beta 3$-adrenergic receptors in the heart: selective agonism and $\beta$-blockade. J Cardiovasc Pharmacol 2017;69:71-78.

38. Wagg A, Nitti VW, Kelleher C, Castro-Diaz D, Siddiqui E, Berner T. Oral pharmacotherapy for overactive bladder in older patients: mirabegron as a potential alternative to antimuscarinics. Curr Med Res Opin 2016;32:621-638.

39. Betmiga 50mg prolonged-release tablets: Summary of Product Characteristics (25 September 2017). Available at https://www.medicines.org.uk/emc/ product/7540/smpc (last accessed 21 November 2018).

40. Skeberdis VA, Gendvilien $\beta$ V, Zablockaite $D$, Treinys $R$, Mačianskienė R, Bogdelis $A$, Jurevičius J, Fischmeister R. $\beta 3$-adrenergic receptor activation increases human atrial tissue contractility and stimulates the L-type $\mathrm{Ca} 2+$ current. J Clin Invest 2008;118:3219-3227.

41. Brodde $0-E_{1}$ Michel MC. Adrenergic and muscarinic receptors in the human heart. Pharmacol Rev 1999;51:651-689.

42. European Medicines Agency. Assessment report: Betmiga. Committee for Medicinal Products for Human Use (CHMP), 2012. Available at https://www.ema. europa.eu/documents/assessment-report/betmiga-epar-public-assessmentreport_en.pdf (last accessed 21 November 2018).

43. Astellas Pharma US, Inc. Prescribing information for MYRBETRIQ (mirabegron extended-release tablets) for oral use. Revised: 4/2018. Available at https://www. us.astellas.com/docs/Myrbetriq_WPI.pdf (last accessed 21 November 2018).

44. Krauwinkel W, van Dijk J, Schaddelee M, Eltink C, Meijer J, Strabach G, van Marle $S$, Kerbusch V, van Gelderen M. Pharmacokinetic properties of mirabegron, a $\beta 3$-adrenoceptor agonist: results from two phase I, randomized, multiple-dose studies in healthy young and elderly men and women. Clin Ther 2012;34:21442160.

45. Chapple CR, Cardozo L, Nitti VW, Siddiqui E, Michel MC. Mirabegron in overactive bladder: a review of efficacy, safety, and tolerability. Neurourol Urodyn 2014;33:17-30.

46. Wagg A, Franks B, Ramos B, Berner T. Persistence and adherence with the new beta-3 receptor agonist, mirabegron, versus antimuscarinics in overactive bladder: Early experience in Canada. Can Urol Assoc J 2015;9:343-350.

47. Batista JE, Kölbl H, Herschorn S, Rechberger T, Cambronero J, Halaska M, Coppell $A$, Kaper $M$, Huang M, Siddiqui E; BEYOND study group. The efficacy and safety of mirabegron compared with solifenacin in overactive bladder patients dissatisfied with previous antimuscarinic treatment due to lack of efficacy: results of a noninferiority, randomized, phase Illb trial. Ther Adv Urol 2015;7:167-179.

48. Kelleher C, Hakimi Z, Zur R, Siddiqui E, Maman K, Aballéa S, Nazir J, Chapple C. Efficacy and tolerability of mirabegron compared with antimuscarinic monotherapy or combination therapies for overactive bladder: a systematic review and network meta-analysis. Eur Urol 2018;74:324-333.

49. Gormley EA, Lightner DJ, Faraday M, Vasavada SP. Diagnosis and treatment of overactive bladder (non-neurogenic) in adults: AUA/SUFU guideline amendment. J Urol 2015;193:1572-1580.

50. Drake MJ, Chapple C, Esen AA, Athanasiou S, Cambronero J, Mitcheson D, Herschorn S, Saleem T, Huang M, Siddiqui E, Stölzel M, Herholdt C, MacDiarmid S. Efficacy and safety of mirabegron add-on therapy to solifenacin in incontinent overactive bladder patients with an inadequate response to initial 4-week solifenacin monotherapy: a randomised double-blind multicentre phase 3B study (BESIDE). Eur Urol 2016;70:136-145.

51. Abrams $P$, Kelleher $C$, Staskin $D$, Rechberger $T$, Kay R, Martina R, Newgreen $D$, Paireddy $A$, van Maanen $R$, Ridder A. Combination treatment with mirabegron and solifenacin in patients with overactive bladder: efficacy and safety results from a randomised, double-blind, dose-ranging, phase 2 study (Symphony). Eur Urol 2015;67:577-588.

52. Herschorn $S$, Chapple $C R$, Abrams $P$, Arlandis $S$, Mitcheson D, Lee K-S, Ridder $A$, Stoelzel M, Paireddy A, van Maanen R, Robinson D. Efficacy and safety of combinations of mirabegron and solifenacin compared with monotherapy and placebo in patients with overactive bladder (SYNERGY study). BJU Int 2017; 120:562-575

53. Wagg A, Cardozo L, Nitti VW, Castro-Diaz D, Auerbach S, Blauwet MB, Siddiqui E. The efficacy and tolerability of the $\beta 3$-adrenoceptor agonist mirabegron for the treatment of symptoms of overactive bladder in older patients. Age Ageing 2014;43:666-675.

54. Nitti VW, Khullar V, van Kerrebroeck $P$, Herschorn $S$, Cambronero J, Angulo JC, Blauwet MB, Dorrepaal C, Siddiqui E, Martin NE. Mirabegron for the treatment of overactive bladder: a prespecified pooled efficacy analysis and pooled safety analysis of three randomised, double-blind, placebo-controlled, phase III studies. Int J Clin Pract 2013;67:619-632.

55. Chapple CR, Kaplan SA, Mitcheson D, Klecka J, Cummings J, Drogendijk T, Dorrepaal C, Martin N. Randomized double-blind, active-controlled phase 3 study to assess 12-month safety and efficacy of mirabegron, a $\beta 3$-adrenoceptor agonist, in overactive bladder. Eur Urol 2013;63:296-305.

56. Rosa GM, Ferrero S, Nitti VW, Wagg A, Saleem T, Chapple CR. Cardiovascular safety of $\beta 3$-adrenoceptor agonists for the treatment of patients with overactive bladder syndrome. Eur Urol 2016;69:311-323.

57. Groen-Wijnberg $M_{1}$ van Dijk J, Krauwinkel W, Kerbusch V, Meijer J, Tretter R, Zhang $W$, van Gelderen M. Pharmacokinetic interactions between mirabegron and metformin, warfarin, digoxin or combined oral contraceptives. Eur J Drug Metab Pharmacokinet 2017;42:417-429.

58. Gravas S, Cornu JN, Drake MJ, Gacci M, Gratzke C, Herrmann TRW, Madersbacher S, Mamoulakis C, Tikkinen KAO. EAU management of non-neurogenic male LUTS guidelines 2017. Available at https://uroweb.org/guideline/treatment-of-nonneurogenic-male-luts/ (last accessed 21 November 2018).

59. Kaplan SA, Roehrborn CG, Abrams P, Chapple CR, Bavendam T, Guan Z. Antimuscarinics for treatment of storage lower urinary tract symptoms in men: a systematic review. Int J Clin Pract 2011;65:487-507.

60. Nitti VW, Rosenberg S, Mitcheson DH, He W, Fakhoury A, Martin NE. Urodynamics and safety of the $\beta 3$-adrenoceptor agonist mirabegron in males with lower urinary tract symptoms and bladder outlet obstruction. J Urol 2013;190:13201327.

61. Eskandar OS, Eckford SD, Whittaker KW. Treatment of overactive bladder (OBA) with anti-cholinergic drugs and the risk of glaucoma. J Obstet Gynaecol 2005;25:419-421.

62. Novack GD, Lewis RA, Vogel R, Sheth N, Swearingen D, Rasmussen S, Hantsbarger G, Martin NE. Randomized, double-masked, placebo-controlled study to assess the ocular safety of mirabegron in healthy volunteers. J Ocul Pharmacol Ther 2013;29:674-680. 